\title{
EFFECT OF LOCKDOWN ON EDUCATION OF RURAL UNDERGRADUATE STUDENTS DURINGCOVID-19 PANDEMIC IN UMARBAN (DHAR), M.P., INDIA
}

\author{
JYOTI AGRAWAL
}

Government College, Umarban- 454449, Dhar (M.P.) India

Email: jvotiagrawal111@rediffmail.com

Received: 31 March 2021, Revised and Accepted: 16 April 2021

\begin{abstract}
A survey was conducted to assess the impact of lockdown due to COVID-19 on online education of undergraduate learners of government colleges Umarban, district Dhar (454449) Madhya Pradesh, India. An online as well as offline survey was conducted from 10 October 2020 to 15 March 2021 to collect the information. To analyze the possibility and attention of students for online education, various online quizzes were conducted in which a structural questionnaire link using 'Google form' was sent to students through WhatsApp. A total of 265 students were taken for the survey. The simple percentage distribution was used to assess the learning status of the study participants. During the lockdown period, around $15.47 \%$ of learners were involved in e-learning. Most of the learners were used android mobile for attending e-learning. The present study revealed that around $60 \%$ of students were seen to involve in farming during lockdown instead of online classes. In addition to this, $45 \%$ of students never joined an online class during the entire session. Further analysis demonstrated that $13 \%$ of students do not have their own mobile phone, nearly $18 \%$ could not join due to poor internet connectivity, $21 \%$ of students faced unfavorable study environment at home and $3 \%$ of students have other reasons. This study also showed a comparative analysis of the presence of students before and after the COVID 19 pandemic. As the ratio of presence of students in physical and virtual classrooms was 2.32 . The overall results from this study revealed that especially in rural areas COVID - 19 pandemic had affected more adversely on classroom attendance, where people already do not want to give importance to education. Higher education institutions may benefit from these findings while formulating strategies to support students during this pandemic. Moreover, to promote education in COVID 19 era strong strategies are urgently needed.
\end{abstract}

Keywords: COVID-19, College students, Rural education, E-learning, Lockdown, Online classes, Poverty, Unawareness for education.

(C) 2021 The Authors. Published by Innovare Academic Sciences Pvt Ltd. This is an open access article under the CC BY license (https://creativecommons.org/licenses/by/4.0/). DOI: https://dx.doi.org/10.22159/ijoe.2021v9i3.41647. Journal homepage: https://innovareacademics.in/iournals/index.php/ijoe

\section{INTRODUCTION}

The coronavirus pandemic is the defining global health disaster of our time and the greatest challenge we have faced in this decade (Goyal, 2020). No one in the world is untouched by the current COVID-19 pandemic. However, its impact and consequences are felt differently depending on the source of earning, education, family background, age, working status, etc. of individuals. Some people are trying to adapt to working online, home schooling their children, online classes, elearning, but some have no choice but to be exposed to the virus while keeping society functioning (Goyal, 2020; Kapasia et al., 2020)

The COVID - 19 disease-causing virus apparently started to spread in China during December 2019, then moved to the rest of the world at the end of January 2020. On 11 March 2020, the World Health Organization (WHO) declared the COVID-19 a pandemic (WHO report, 2020). By 31 July 2020, COVID-19 had spread across $217+$ countries and territories, with almost 17.1 million confirmed cases and 668,073 deaths. The novel coronavirus SARS-CoV-2 (severe acute respiratory syndromecoronavirus-2) has affected all age groups, with the worst manifestations and highest death rates being found among older individuals and patients with comorbidities (Kapasia et al., 2020; WHO report, 2020). COVID-19 is killing people on a large scale. As of 29 March 2021, more than 128,351,047 people across the world had tested positive for the same ("COVID-19", 2021). According to the recent database, at least $2,806,780$ people with the virus have died. In India, till now $1,20,97,154$ cases were found to be confirmed corona positive; out of these 1,62,156 people have been died ("COVID-19", 2021).

Due to the dramatic effects of the first wave of the COVID-19 pandemic in the first four or five months of 2020, huge changes were seen in everyday lives. Most countries affected by the pandemic were able to slow down the spread of the COVID-19 with different levels by imposing drastic measures like banning public events and gatherings, workplace closures, stay-at-home restrictions, restrictions on transport, and shutting educational institutions down (Khattar, Jain, \& Quadri, 2017; Kapasia et al., 2020) that is a lockdown. Physically closing workplaces, including educational institutions (schools, colleges and universities) proved to be an efficient way of minimizing the spread of the virus, yet it has led to many challenges for both students and teachers, but also their families, friends, employers, and thus society and the global economy (Goyal, 2020; McCarthy, 2020). It was seen that reopening after the lockdowns; educational institutions will not encounter the same situation they experienced before the COVID-19 pandemic. For the safety of students and teachers, many guidelines were reformulated (Marinoni, Land, \& Jensen, 2020).

The number of learners required to stay at home due to the closure of their educational institution on all levels. At the higher education level, many drastic changes in the education system were seen, as the switch to online lectures/tutorials, closed libraries, changed communication channels for teacher's and administrative support, new assessment methods, different workloads and performance levels etc. (Marinoni et al., 2020; McCarthy, 2020). In addition to this, many indirect effects on student's education and social life were also observed like no meetings with friends, university colleagues or relatives, no parties, no traveling, remaining trapped abroad loss of student job, worries about their own financial situation, etc. (Kapasia et al., 2020). Because of all these, most of the students were seen to in fear for future education and career, frustrations, anxiety, anger, boredom, etc. (Jena, 2020).

UNESCO (United Nations Educational Scientific and Cultural Organization) report showed that around 1.3 billion learners across the world were not able to attend schoolor university as of 23 March 2020, and current UNESCO statistics put this figure at over 1.5 billion (McCarthy, 2020). Due to long breaks from school and colleges, many students have lost their interest and zeal for studies (Crawford et al., 2020). In the present study, we 
have studied the impact of lockdown on the education of college students in an interior rural area. Where people are mostly involved in farming and the percentage of education is already very less (Bernard et al., 2004).

This research paper intends to critically understand the issues related to the impact of the COVID-19 pandemicon sudden shift of education to the online mode of teaching and learningand the challenges of the online mode of education in the rural area of Dhar district in Madhya Pradesh, India. The paper also aims to explore the practical issues of rural students with special reference to e-learning. The paper ends with a discussion and conclusions in which the main findings, limitations, and future research avenues are considered.

\section{REVIEW OF THE RELATED LITERATURE}

The speedy evolution of COVID-19 at such a large scale has influenced students of all age groups. It has already been mentioned that the continued spread of the disease, travel restrictions and the closure of educational institutions across the country showed a noteworthy effect on the education, social life, and mental health of students (Gonzalez et al., 2020). Especially the students from rural backgrounds have experienced larger negative impacts due to the Covid-19 outbreak (Bao, 2020). These measures can have long-term consequences on the lives of students (Cohen, Hoyt, \& Dull, 2020). Due to COVID-19, all education was shifted to online modes, which were proved to a great challenge for rural educations, where little success has been recorded all over the world.

Long-term lockdown reduction in family income, inadequate access to digital resources, and limited internet connectivity have disrupted the academic life of the students. Recent findings revealed that more than 1.5 billion students across the world are now deprived of basic education (Cao et al., 2020). In addition to this, the same has also affect the income of many self-dependent students. Changes in daily routine, including lack of outdoor activity, disturbed sleeping patterns, social distancing, family stress and economic burden etc., have affected the mental well-being of the students (Cook, 2009; Cohen et al., 2020).

Another major factor behind the same is less attention of students towards higher education as these are mainly involved in farming in rural areas. Attending online classes requires an efficient android phone, leave from farming jobs, long hours of internet, and peaceful space for each student in a family (Cook, 2009). It was observed that the same was not affordable for everyone. Economic inefficiency was found to be a major cause to keep many untouched students from education during the entire period of lockdown (McCarthy, 2020). Earlier studies demonstrated that this might have added feelings of helplessness and shame among such kinds of students (Gonzalez et al., 2020; McCarthy, 2020).

Moreover, many students even after having their own android phones were unable to keep continue their education as they were not accustomed or trained to use education applications and search engines (Saha, Barman, \& Chouhan, 2020). In the last one-year much research on the effects of Covid-19 and lockdown on the education of students has been done, which demonstrated a lot of causes and adverse effects of lockdown during COVID-19 pandemic on the education of undergraduates.

\section{SIGNIFICANCE OF THE STUDY}

- This study is helpful to reveal the impact of lockdown on the education of college students in an interior rural area where people do not give importance to education and students mostly involved in farming.

- This research also elucidates the practical issues of rural students with special reference to e-learning.

- The findings of this study are useful to educationists, especially curriculum developers and teachers, to adopt appropriate teaching and learning strategies to promote education during pandemics or other emergencies, especially for economically weak rural students.

- The findings and recommendations of this study will also serve as a source of reference material for students and teachers to acquire actual knowledge of technology available in rural India.

- The potential consequences of the COVID-19 pandemic on the life of students are investigated.

- The outcomes suggested that economically incapables students must be given physical assets to keep continuing their e-learning. Otherwise, great differences between the education level of economically capable and incapables will emerge.

- This investigation also revealed a wide gap between government policies and the actual situations.

\section{OBJECTIVES}

This research work was conducted to understand the issues related to the impact of the COVID-19 pandemic on the sudden shift of education to the online mode of teaching and learning and challenges of the online mode of education in a specific rural area in Madhya Pradesh, India.

\section{RESEARCH QUESTION}

What are the effects of lockdown on the education of rural undergraduate students during the COVID-19 pandemic in Umarban (Dhar), M.P., India?

\section{HYPOTHESES}

There is no significant impact of COVID - 19 on educations of undergraduate students as other tools of educations such as online classes and internet-based learning is available to all class of students.

\section{METHODOLOGY}

The target population comprised higher education students who were at least 16 years old. These are all undergraduate students of Government College Umarban, district Dhar, Madhya Pradesh, India. An online and an offline survey were conducted from 10 October 2020 to 15 March 2021 to collect the information. To analyze the attention of students for online education, various online quizzes were conducted in which a structural questionnaire link using 'Google form' was sent to students through WhatsApp. The data was collected from online class attendance during the lockdown and also physical classroom after the reopening of colleges. A total of 265 students was taken for this study, of which 93 students are boys and 172 are girls. These are all belonging to the same village and nearby area. The simple percentage distribution was used to assess the learning status of the study participants. In addition to the academic year 2020, the data of the previous year was also compared.

\section{RESULTS AND DISCUSSION}

The present study showed that out of a total of 265 students, an average of $14.7 \pm 3.2(15.5 \%)$ were present in online classes. Out of 172 female students, $33.6 \pm 5.6$ (19.3) were almost present. On the other hand, only 8.2 \pm 2.4 (8.7) male students out of 93 showed online presence. The physical classes were reopened from the third week of January 2021. After this, the classroom attendance of the same students was reported to be nearly more than double that of an online presence. The data showed $35.47 \%$ overall presence, $42.44 \%$ presence for female and $22.5 \%$ presence for male students, respectively. The above data revealed the significance of physical classes over virtual classes. Though online classes have many advantages over offline classes then also here, rural students were observed to prefer offline classes (Bernard et al., 2004). 
The attendance of students in online quizzes and webinars was also illustrated that many students were always absent in all elearning activities. As the data from Figures 1 and 2 showed that only a few students attended the above-mentioned college activities. Though many students were seen to neutral for such activities after all availability of required facilities too, this may be due to a lack of interest for e-learning.

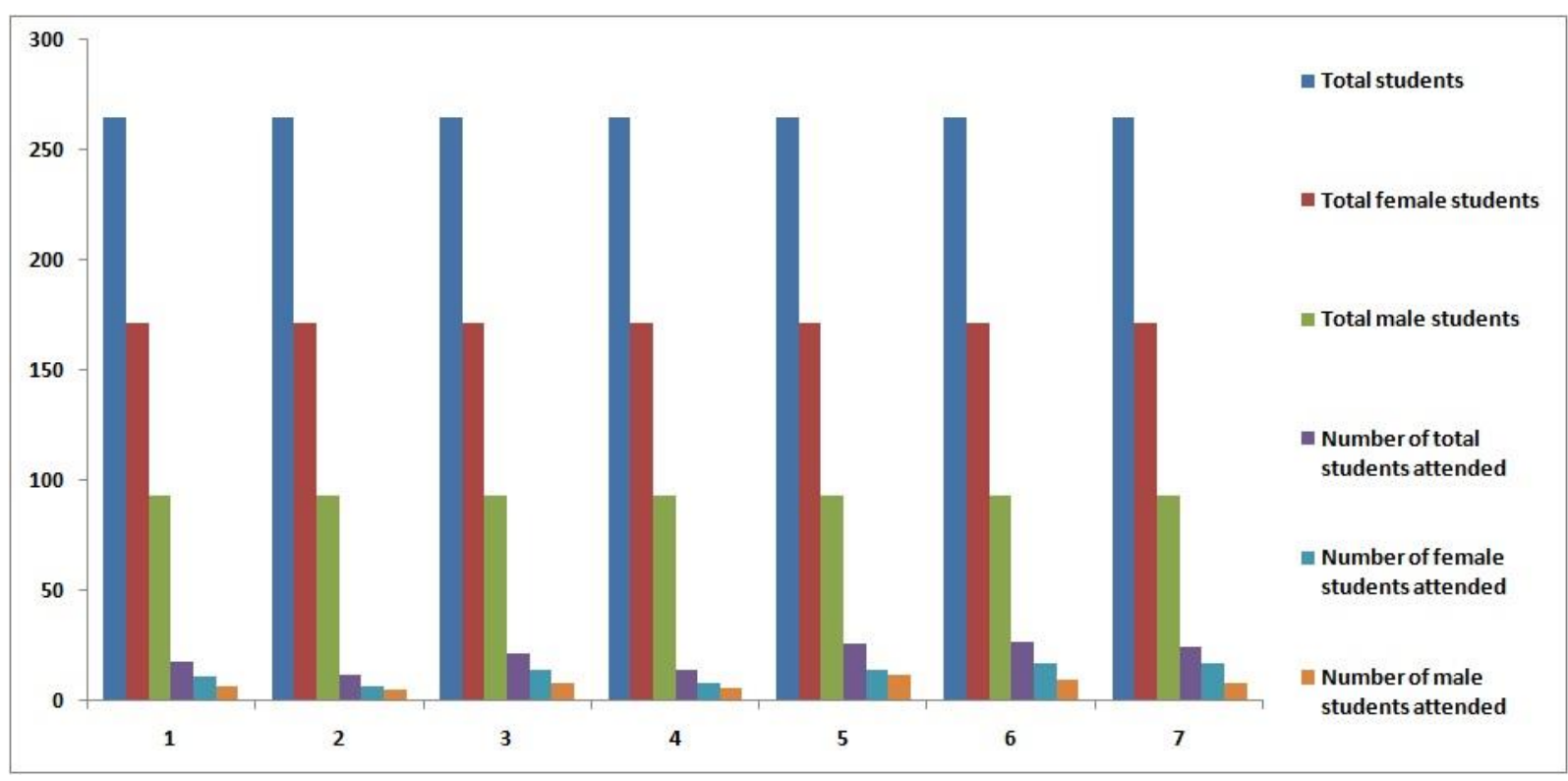

Fig. 1: Number of college students in online quizzes conducted by the college itself during lockdown period and after reopening of colleges for studied population

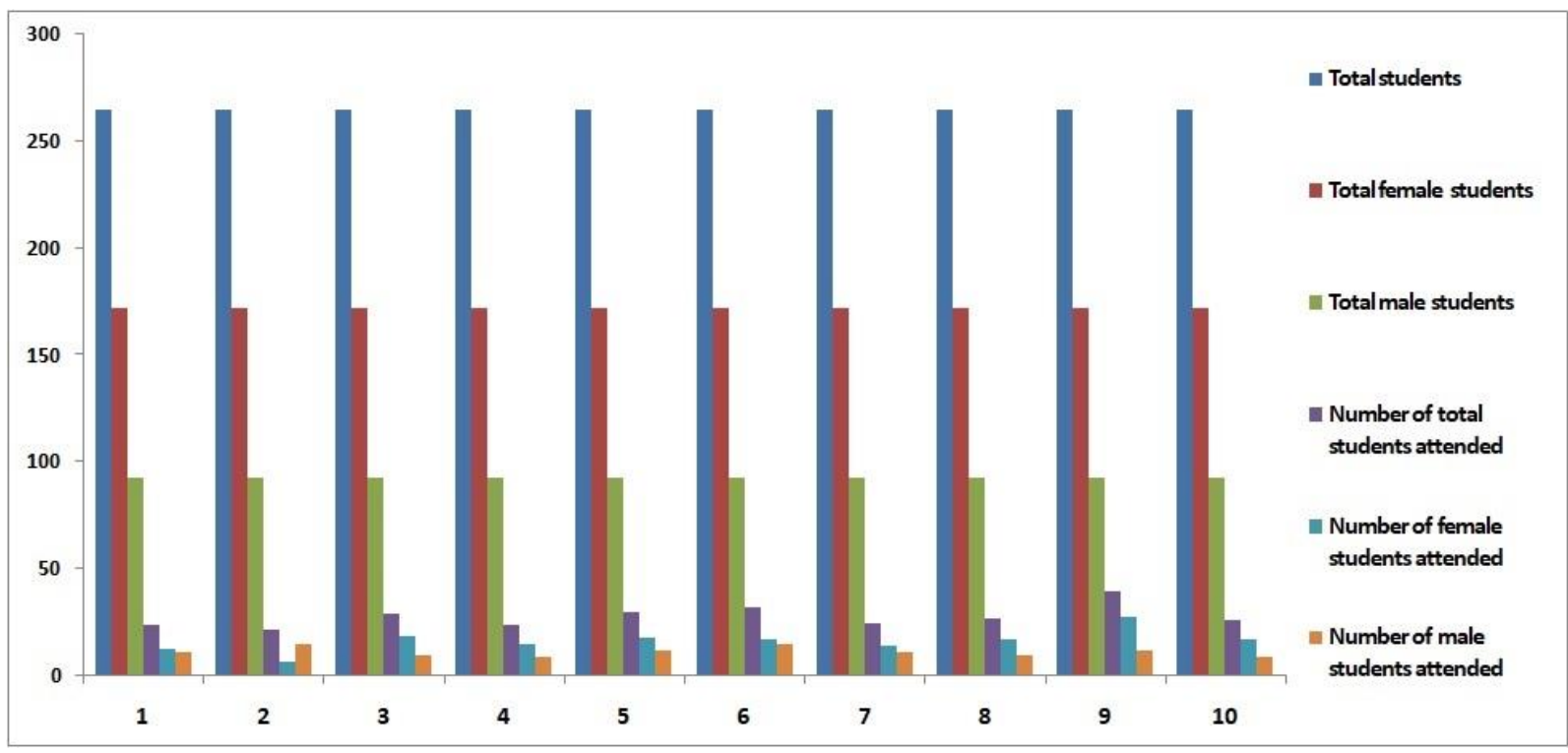

Fig. 2: Number of college students present in different webinars during lockdown and reopening of colleges for the studied population

As e-learning allows students to attend classes from any location of their choice. It also allows recording and future sharing of online lectures. This also allows students to access the learning material at a time of their comfort (Bernard et al., 2004; Manzoor, 2020). In addition to this, e- earning reduces financial costs as this eliminates the cost points of student transportation, student meals, and most importantly, a paperless learning environment that is more affordable while also being beneficial to the environment (Goyal, 2020). But, then also students showed less interest in e-learning. Further, a comparison of presence records of students in the academic year 2020-21 and 2019-20 showed that many students not to come at institution after reopening. As almost $82.6 \%$ of students were present in institute before COVID-19 which was reduced to $35.5 \%$ after COVID-19 era. Many students were interviewed to know the reasons in this particular area. Findings showed that students do not enjoy e-learning as the same can learn a lot from being in the company of their peers. Though, in an online class, there are minimal physical interactions between students and teachers. This often results in the sense of isolation for the students (Khattar et al., 2017; Marinoni et al., 2020).

One of the major causes of less interest of students was the struggle with focusing on the screen for long periods of time. 
With online learning, there is also a greater chance for students to be easily distracted by social media or other sites, as the same were reported with many students (Bernard et al., 204; Kapasia et al., 2020). Another key challenge of online classes is internet connectivity, especially in rural zones. In our studied population, about $18 \%$ of students could not join online classes due to inappropriate internet connectivity (Jena, 2020; Saha et al., 2020). Without a consistent internet connection for students or teachers, there can be a lack of continuity in learning. This was seen to be a detrimental cause for online education process (Khan, 2008; Jindal, \& Chahal, 2018).

Attending online classes requires long hours of internet, peaceful space and one device/ phone dedicated to each student in a family, which might not be affordable for everyone. In our sample population, about $13 \%$ of students do not have android mobile phones (Crawford et al., 2020). As many students are economically poor and unable to afford mobile phone these were completely untouched from education during the entire period of lockdown (Saha et al., 2020). Earlier studies demonstrated that platforms of online classes had added feelings of vulnerability and shame among such kinds of students (Cao et al., 2020).

National Sample Survey on Key Indicators of Household Social Consumption on Education in India report of 2017-18 showed that less than $15 \%$ of rural Indian households have internet (as opposed to $42 \%$ urban Indian households) (Jindal, \& Chahal, 2020; Manzoor, 2020). The poorest households, farmers and labor class people cannot afford a smartphone or a computer (Cook, 2009; Cohen et al. 2020). The present study also showed similar findings where almost $94 \%$ of students belong to farmer's families.

Many students even after having their own smartphones were unable to access online learning as they were not accustomed or trained to use education applications and search engines (Cohen et al. 2020). Earlier data also revealed that this is a significant issue in rural and lower socioeconomic neighborhoods (Cook, 2009; Cohen et al., 2020; Manzoor, 2020). As far as Internet accessibility is concerned, it is again a significant cost to the user. This system has not only led to the exclusion of students from poor and marginalized backgrounds from digital learning but also pushed many underprivileged students towards depression and anxiety (Jena, 2020). This pandemic has exposed the deeply rooted inequality and hierarchy between the rich and poor in the Indian education system (Crawford et al., 2020). The financial growth of such poor students can be accomplished with a better approach to education. Due to online classes, the same has again raised as a barrier for the same students (McCarthy, 2020).

One more major cause of less presence of students in online classes is so much engagement on social media and distractions on various channels (Crawford et al., 2020; Manzoor, 2020). It was also seen that many times students have all the required facilities to attend online classes, but they do not put their attention on classes. While in offline classes also some students were seen to engage with their mobile phones. The same scene is felt in many places where both school and college students spend a lot of time with social media that led them away from the study. This is also a great challenge in the present era (Bernard et al., 2004; Crawford et al., 2020; Kapasia et al., 2020; Jena, 2020).

However, e-learning is transforming remote rural areas. While many are making the most of what online learning offers, local authorities are finding it tough to integrate high-speed internet facilities (Stalin, Abraham, Kanimozhy, Prasad, Singh, \& Purty, 2016). Moreover, people in rural areas have to deal with intermittent power supply and older electronic devices, which was seen to hinder flawless access (Crawford et al., 2020). Recent data also demonstrated that students in rural India are denied the newest devices and levels of accessibility to online content that urban Indians enjoy daily. Unlike their counterparts in cities, a lower percentage of students in villages possess desktop or laptop computers (Bernard et al., 2004; Jena, 2020).
They depend on their family members' mobile phones for learning and attending classes, making it a strenuous exercise (Khan, 2008; Cohen et al., 2020). Watching small screens to consume as much information as possible for long hours was observed to detrimental to students' health (Stalin et al., 2016). Digital literacy and the digital divide have been serious concerns for our country for over a decade. Many teachers and students in rural areas are not able to match up to the technical skills of educationalists and students in cities (Crawford et al., 2020; Kapasia et al., 2020; Jena, 2020).

Some studies showed that both teachers and students are facing discomfort during working. Here, a strong need for collective efforts of civil society organizations, policymakers and the government is felt to create an equal, user-friendly digital interface so that teachers and students find it conducive for uninterrupted learning (Jindal, \& Chahal, 2020; Manzoor, 2020).

This research work may provide deep insight and the exact situation in remote rural areas in central India. Higher education institutions may benefit from these findings while formulating strategies to support students during this pandemic. Moreover, to promote education in COVID 19 era strong strategies are urgently needed. Furthermore, the same analysis in different zones may also be helpful to put forward better understandings.

\section{CONCLUSION}

Online classes have become an alternative to regular classes under the circumstances of the present pandemic. Smartphones, computers, internet and technology services need to be considered as a necessity and not a luxury. In the present analysis, the picture of a remote rural area was presented, where students are more inclined for physical classrooms over virtual classrooms. The main reasons were the unavailability to smartphone to the students, poor internet connectivity, not much facility to access internet data, etc. The same study also revealed that as most of the students belong to farmer's families so instead of online classes, they need to work in fields. This analysis also finds that less face-to-face interaction between teacher and students, absence of classmates, network problems, new structure of classes cause irritation, frustration and anxiety among studied students. Here, a dramatic decrease in the presence of students in online classrooms was reported. Some tools like social presence during the online course, asking student's personal information, encouraging interaction exchange between students, supporting video communications may help to increase their interest and approach in virtual classes.

\section{ACKNOWLEDGEMENT}

The In-charge principal, Ms. Prerana Sikarwar, Government College Umarban, District Dhar and Administrative Officer, Mrs. Prabina Yadav, Government College Umarban, District Dhar, Madhya Pradesh, India are greatly acknowledged for their kind support and permission to publish college data.

\section{AUTHOR'S CONTRIBUTIONS}

I, Dr. Jyoti Agrawal, assistant professor, Government College Umarban, District Dhar, Madhya Pradesh, India has done the above complete research work. I am also an online and offline class in-charge in our college. I conducted all above mentioned online quizzes, webinars and collected data to highlight the current scene of higher education in the given rural area. To understand the situation and psychology of students toward online classes and e-learning, I contacted them and asked questions.

\section{CONFLICT OF INTEREST}

No conflict

\section{FUNDING SOURCE}

Nil 


\section{REFERENCES}

- Bao, W. (2020). COVID-19 and online teaching in higher education: A case study of Peking University. Human Behavior and Emerging Technologies, 2, 113-115. doi.org/10.1002/hbe2.191

- $\quad$ Bernard, R. M., Abrami, P. C., Lou. Y., Borokhovski, E., Wade, A., \& Wozney, L. (2004). How does distance education compare with classroom instruction? A metaanalysis of the empirical literature. Review of Educational Research, 74(3), 379-439. doi.org/10.3102/00346543074003379

- $\quad$ Cao, W., Fang, Z., Hou, G., Han, M., Xu, X., Dong, J., \& Zheng, J. (2020). The psychological impact of the COVID-19 epidemic on college students in China. Psychiatry Research, 287 ,

112934. doi.org/10.1016/j.psychres.2020.112934

- Cohen, A. K., Hoyt, L. T., \& Dull, B. (2020). A descriptive study of coronavirus disease 2019-related experiences and perspectives of a national sample of college students in spring 2020. Journal of Adolescent Health, 67(3), 369375. doi.org/10.1016/i. jadohealth.2020.06.009

- Cook, D. A. (2009). The failure of e-learning research to inform educational practice and what we can do about it.

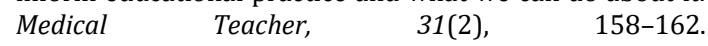
doi.org/10.1080/01421590802691393

- COVID-19 in India. (2021). Retrieved March 30, 2021, from https://www.covid19india.org/

- COVID-19 in world. (2021). Retrieved March 30, 2021, from https://www.worldometers.info/coronavirus/

- Crawford, J., Henderson, K. B., Rudolph, J., Malkawi, B., Glowatz, M., Burton, R., ... Lam, S. (2020). COVID-19: 20 countries' higher education intra-period digital pedagogy responses. Journal of Applied Learning \& Teaching, 3(1), 120. doi.org/10.37074/jalt.2020.3.1.7

- Gonzalez, T., Rubia, M. A., Hincz, K. P., Comas-Lopez, M., Subirats, L., \& Fort, S., (2020). Influence of COVID-19 confinement on students' performance in higher education. PLoS ONE, 15(10). e0239490. doi.org/10.1371/journal.pone.0239490

- Goyal, S. (2020). Impact of coronavirus on education in India, 2020. Retrieved from Jagran Josh website: https://www.jagranjosh.com/general-

knowledge/impact-of-coronavirus-on-education-in-india$\underline{1587642880-1}$

- Jena, P. K., (2020). Impact of COVID-19 on higher education in India. International Journal of Advanced Education \& Research, 5(3), 77-81.

- Jindal, A., \& Chahal, B. P. S. (2018). Challenges and opportunities for online education in India. Pramana Research Journal, 8(4), 99-105.

- $\quad$ Kapasia, N., Paul, P., Roy, A., Saha, J., Zaveri, A., Mallick, R.,
... Chouhan, P. (2020). Impact of lockdown on learning status of undergraduate and postgraduate students during COVID-19 pandemic in West Bengal, India. Children and Youth Services Review, 116, 105194. doi.org/10.1016/i.childyouth.2020.105194

- $\quad$ Khan, M. M. (2008). Adverse effects of excessive mobile phone use. International Journal of Occupational Medicine and Environmental Health, 21(4), 289-293. doi.org/10.2478/v10001-008-0028-6

- $\quad$ Khattar, A., Jain, P. R., \& Quadri, S. M. K. (2017). Effects of the disastrous pandemic COVID 19 on learning styles, activities and mental health of young Indian students- A machine learning approach. Proceedings of the $4^{\text {th }}$ International Conference on Intelligent Computing and Control Systems (ICICCS), Madurai, India: India. Retrieved from

https://ieeexplore.ieee.org/document/9120955/citation s\#citations. doi: 10.1109/ICICCS48265.2020.9120955

- Manzoor, A. (2020). Online teaching and challenges of covid-19 for inclusion of persons with disabilities in higher education. Retrieved from Daily Times website: https://dailytimes.com.pk/595888/online-teaching-andchallenges-of-COVID-19-for-inclusion-of-pwds-inhighereducation/

- $\quad$ Marinoni, G., Land, H. V., \& Jensen, T. (2020). The impact of Covid-19 on higher education around the world. Retrieved from https://www.iauaiu.net/IMG/pdf/iau_covid19_and_he_survey_report_final_ may 2020.pdf

- McCarthy, N. (2020). COVID-19's staggering impact on global education. Retrieved from World Economic Forum website:

https://www.weforum.org/agenda/2020/03/infographic -COVID19-coronavirus-impact-global-education-healthschools/

- $\quad$ Saha, J., Barman, B., \& Chouhan, P. (2020). Lockdown for COVID-19 and its impact on community mobility in India: An analysis of the COVID-19 Community Mobility Reports, 2020. Children and Youth Services Review, 116, Article 105160. doi. org/10.1016/i.childyouth.2020.105160

- $\quad$ Stalin, P., Abraham, S. B., Kanimozhy, K., Prasad, R. V., Singh, Z., \& Purty, A. J. (2016). Mobile phone usage and its health effects among adults in a semi-urban area of southern India. Journal of Clinical \& Diagnostic Research, 10(1), LC14-LC16.

- World Health Organization. (2020). WHO directorgeneral's opening remarks at the media briefing on COVID19. Retrieved June 25, 2020, from https://www.who.int/directorgeneral/speeches/detail/who-director-general-sopening-remarks-at-the-media-briefing-on-covid-19--11-march-2020 